\title{
Influence of Different Cowpea (Vigna unguiculata (L.) Walp.) Genotypes from Burkina Faso on Proteases Inhibition
}

\author{
Pierre Alexandre Eric Djifaby Sombié ${ }^{1, ~ *}$, Ahmed Yacouba Coulibaly ${ }^{2}$, Adama Hilou ${ }^{3}$, \\ Martin Kiendrebéogo ${ }^{3}$ \\ ${ }^{1}$ Department of Crop Production, Institute of Environment and Agricultural Research (INERA), Ouagadougou, Burkina Faso \\ ${ }^{2}$ Unit of formation and Research in Sciences and Technology, University Norbert Zongo, Koudougou, Burkina Faso \\ ${ }^{3}$ Laboratory of Biochemistry and Chemistry Applied (LABIOCA), Department of Biochemistry-Microbiology, University of Ouagadougou, \\ Ouagadougou, Burkina Faso
}

\section{Email address:}

ericsombie@yahoo.fr (P. A. E. D. Sombié), coulahmede@yahoo.fr (A. Y. Coulibaly), hiloudio@gmail.com (A. Hilou), martinkiendrebeogo@yahoo.co.uk (M. Kiendrébéogo)

${ }^{*}$ Corresponding author

\section{To cite this article:}

Pierre Alexandre Eric Djifaby Sombié, Ahmed Yacouba Coulibaly, Adama Hilou, Martin Kiendrebéogo. Influence of Different Cowpea (Vigna unguiculata (L.) Walp.) Genotypes from Burkina Faso on Proteases Inhibition. Advances in Biochemistry.

Vol. 7, No. 1, 2019, pp. 15-21. doi: 10.11648/j.ab.20190701.14

Received: April 6, 2019; Accepted: May 23, 2019; Published: June 11, 2019

\begin{abstract}
Cowpea is an important protein crop widespread in Africa. The purpose of this research was to determine the content of trypsin and chymotrypsin inhibitors in different genotypes of cowpea seeds. Trypsin percentage inhibition showed about 13.5 -fold variation $(5.12 \% \pm 1.47$ to $70.52 \% \pm 6.58)$ between the cowpea genotypes respectively for $\mathrm{KVx} 421-2 \mathrm{~J}$ and Kondèsyoungo local. The chymotrypsin inhibitory activity varies among cowpea genotypes from 21.19 to $76.94 \%$. The highest percent inhibitory activity was exhibited by KVx 396-4-5-2D on chymotrypsin. This study also showed significant correlations between type of cowpea genotype and trypsin inhibition potential and also between colour and chymotrypsin inhibition potential of cowpea seeds. Kondèsyoungo local, a landraceae genotype exhibited the high potential to inhibit the trypsin enzyme. Coloured seeds of cowpea genotypes possess higher percentage inhibition of chymotrypsin than the colourless ones ( $p$ $<0.05)$. The calculated mean of trypsin and chymotrypsin inhibition activities showed that Labagela local genotype possess the highest inhibition activity of both protease enzymes. The PCA components analysis and the dendrogram performed basis on the protease inhibitory activities divided the thirty-one genotypes of cowpea used in this study into three classes. The results presented in this work can contribute greatly to the planning of a cowpea breeding program aimed at reducing the content of proteases inhibitors in order to improve the nutritional value of seeds or to increase PI content for tolerance to stored grain pests.
\end{abstract}

Keywords: Cowpea, Trypsin, Chymotrypsin, Genotypes

\section{Introduction}

Pulses are crops cultivated for their dry seeds and they have much protein than cereals [1]. Cowpea (Vigna unguiculata (L.) Walp) is an important staple legume crop of African origin that is grown worldwide [2-4]. This legume provides an important source of protein, soluble sugar, amino acids, vitamins and minerals for human consumption and animal feeding especially in the lower income countries [2, 4, 5]. Previous studies showed that Burkina Faso cowpea cultivars are rich in mineral elements (Fe, $\mathrm{Zn}, \mathrm{Mg}, \mathrm{Ca}, \mathrm{Se}, \mathrm{K}$, $\mathrm{Na})$, phenolic compounds and have significant antioxidant and anti-lipid peroxidation activities [5, 6]. Legumes also contain antinutritional factors like saponin, heamaglutinin, cyanogenic glycoside, phytic acid, tannin, trypsin and chymotrypsin inhibitors that may reduce the bioavailability of nutrients and also cause harmful effects to human health 
$[7,8]$. Storage organs of plant such as seeds, tubers and also leaves, flowers, and fruits contain different types of protease inhibitors (PIs) which is able to inhibit some enzymes like trypsin, pepsin and chymotrypsin $[9,10,7,11]$. PIs are small proteins or peptides that inhibit the catalytic action of proteases by forming stoichiometric and stable complexes with their proteolytic enzymes blocking or altering the active site [11-13]. Protease inhibitors in legume seed can inhibit pancreatic serine proteases, thus slowing down protein digestion at the small intestine $[14,15]$. The bioavailability of sulfur-containing amino acids (e.g. methionine and cysteine) in legume is lower as a consequence [15]. Various processes in living systems are regulated by protease inhibitors [16]. Protease-inhibitor proteins play five principle functions in plant: (a) endogenous insecticides, (b) modulators of proteases, (c) storage proteins for reduced sulfur-containing amino acids, (d) protection of the embryo sac, (e) defense of plant against non-biological stressors [9]. The positive or negative effect of protease inhibitors in human and animal depend on the level present in the different legumes and on the dose and time of consumption. The level of these inhibitors (trypsin and chymotrypsin) in cowpea seeds from Burkina Faso is little known. The aim of this study is to determine trypsin and chymotrypsin inhibitory activities of some cowpea seeds and their variation among the genotypes.

\section{Material and Methods}

\subsection{Plant Material}

Seeds of thirty-one (31) cowpea (Vigna unguiculata) genotypes were obtained from the germplasm of Genetic and Biotechnology Laboratory, Department of Crop Production, Institute of Environment and Agricultural Research (INERA), CREAF-Kamboinsé, Burkina Faso.

\subsection{Protease Inhibitor Extraction}

The seeds were ground to powder using a coffee grinder and $20 \mathrm{mg}$ of each powder was added to $500 \mu \mathrm{l}$ of extraction buffer $\left(92 \mathrm{mM}\right.$ Tris base $\mathrm{pH} 8.1,23 \mathrm{mM} \mathrm{CaCl}_{2}$ ) and then centrifuged at $14000 \mathrm{rpm}$ for $20 \mathrm{~min}$ in $4^{\circ} \mathrm{C}$.

\subsection{Trypsin and Chymotrypsin Inhibition Assay}

Trypsin and chymotrypsin inhibition assay were determined according to the method described by Klomklao et al [17]. To measure trypsin inhibition activity (TIA), a solution of trypsin (from bovine pancreas, Sigma) was prepared in Tris- $\mathrm{HCl}$ buffer $(0.2 \mathrm{M}, \mathrm{pH} 7.8)$ at a concentration of $12.5 \mu \mathrm{g} \cdot \mathrm{ml}^{-1}$ and $100 \mu \mathrm{l}$ of this solution was mixed with $100 \mu \mathrm{l}$ of cowpea total protein extract. The mixture was incubated for 5 min prior to the addition of $N-\alpha$ Benzoyl-DL-Arginine $p$-Nitroanilide (BAPNA) as substrate $\left(50 \mu \mathrm{l}, 800 \mu \mathrm{g} . \mathrm{ml}^{-1}\right)$ dissolved in Tris- $\mathrm{HCl}$ buffer $(0.05 \mathrm{M} \mathrm{pH}$ 8.2, $\left.0.05 \mathrm{M} \mathrm{CaCl}_{2}\right)$. The liberated $p$-nitroanilide was monitored for $25 \mathrm{~min}$ at $410 \mathrm{~nm}$ using a spectrophotometer 96 wells.

For chymotrypsin inhibition activity (CIA), $\alpha$ Chymotrypsin (from bovine pancreas, Sigma) was prepared in Tris- $\mathrm{HCl}$ buffer $(0.2 \mathrm{M}, \mathrm{pH} 7.8)$ at a concentration of $18.75 \mu \mathrm{g} . \mathrm{ml}^{-1}$ and $100 \mu \mathrm{l}$ of this solution was added to cowpea total protein extract $(100 \mu 1)$. The mixture was incubated for $5 \mathrm{~min}$ prior to the addition of $50 \mu \mathrm{l}$ of $\mathrm{N}$ Glutaryl-L-Phenylalanine $p$-Nitroanilide (GPNA) at 3200 $\mu \mathrm{g} . \mathrm{ml}^{-1}$ dissolved in Tris-HCl buffer $(0.05 \mathrm{M} \mathrm{pH} 8.2,0.05 \mathrm{M}$ $\left.\mathrm{CaCl}_{2}\right)$. The liberated $p$-nitroanilide was monitored for 25 min at $410 \mathrm{~nm}$ using a spectrophotometer 96 wells. A control without inhibitors and a blank without enzyme were also run in the same conditions. Trypsin and chymotrypsin inhibitions by cowpea samples were estimated as percentages inhibition (\%) according to the formula:

$$
\text { Percent inhibition }(\%)=\frac{\text { Vmax contr }- \text { Vmax sample }}{V \max \text { contr }} \times 100
$$

\section{Results}

\subsection{Inhibition Activities of Cowpea Seeds on Trypsin and Chymotrypsin}

Table 1 showed genotypic variation for trypsin and chymotrypsin inhibitory activities in some cowpea genotypes from Burkina Faso. The percentages inhibition of cowpea genotypes seeds extracts on trypsin varies from $5.12 \% \pm 1.47$ to $70.52 \% \pm 6.58$ respectively for $\mathrm{KVx} 421-2 \mathrm{~J}$ and Kondèsyoungo local genotypes, corresponding to about 13.5fold variation. Analysis of variance showed that both Kondèsyoungo local and Gourgou genotypes had the highest and significant effects on trypsin inhibition $(p<0.05)$ followed by CR06-07 and Labagela local genotypes. Fifteen genotypes of cowpea exhibited more than $50 \%$ inhibition on trypsin at the tested concentration of $50 \mathrm{mg} / \mathrm{mL}$ (dry seeds weight).

The chymotrypsin inhibitory activities vary among cowpea genotypes from $21.20 \pm 4.75$ to $76.94 \pm 2.15 \%$ (indicating more than 3.5-fold variation cowpea seeds genotypes). The lowest chymotrypsin inhibitory activity was detected in $\mathrm{KVx}$ 780-3 genotype. The highest one exhibited by KVx 396-4-5$2 \mathrm{D}$ was not significantly different $(\mathrm{p}<0.05)$ from those of IT 93 K-693-2 (75.43 $\pm 5.58 \%), \mathrm{KVx} 65-114$ (75.04 $\pm 0.98 \%)$, Gorom local $(73.84 \pm 3.42 \%)$, Komcallé $(68.98 \pm 0.1 \%)$, TVU $14676(67.28 \pm 3.40 \%)$ and Labagela local $(67.16 \pm$ $3.07 \%)$. Nineteen cowpea genotypes $(50 \mathrm{mg} / \mathrm{mL}$, dry seeds weight) got more than $50 \%$ inhibition on chymotrypsin. Analysis of variance showed that some cowpea genotypes had significant effects on trypsin and chymotrypsin inhibitory activities. 
Table 1. Protease inhibition potentials of cowpea genotypes.

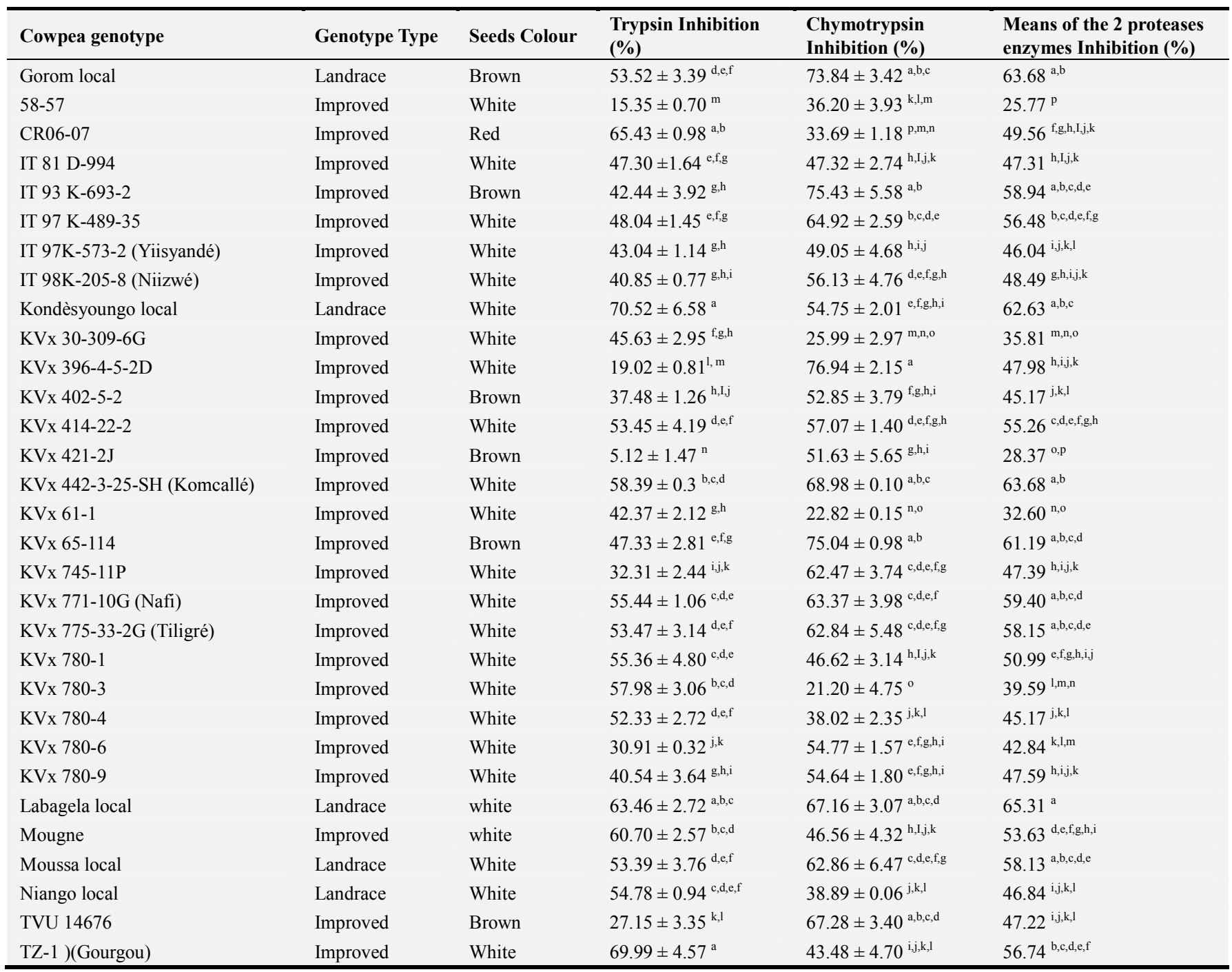

Means in a same column followed by different letter (s) are significantly different at $\mathrm{P}<0.05$

The means calculated of trypsin and chymotrypsin inhibition activities showed that Labagela local genotype possessed the highest inhibition activities of both protease enzymes $(65.31 \pm 2.89 \%)$ followed by Gorom local $(63.68 \pm$ $1.80 \%)$, Komcallé $(63.68 \pm 0.22 \%)$, Kondèsyoungo local $(62.63 \pm 4.30 \%)$ and $\mathrm{KVx} \quad 65-114 \quad(61.19 \pm 1.90 \%)$ genotypes.

\subsection{Seeds Colour and Genotypes Type Contribution to the Inhibition of Protease Enzymes}

The colour of seeds and type of cowpea genotypes is presented in Table 1. The colour of cowpea seeds used in this study varied widely. There are significant correlations between the colour and the chymotrypsin inhibition potential of cowpea seeds. Coloured seeds of cowpea genotypes possess higher percentage inhibition of chymotrypsin than the colourless ones $(p<0.05)$. This clearly shows that seeds coat pigments have also major compounds that contribute to chymotrypsin inhibition activity in cowpea. No significant correlation was observed between trypsin inhibition activity and color of seeds. It is suggested that seeds pigments not seem to influence the trypsin inhibition potential of the cowpea. Twenty-six improved genotypes and five landrace genotypes are used in this study. There was significant correlation between type of cowpea genotypes and trypsin inhibition potential $(\mathrm{p}<0.05)$. The landraceae genotypes showed the significant high inhibition potential of trypsin ( $p$ $<0.05$ ). Kondèsyoungo local, a landraceae genotype exhibited the high potential to inhibit the trypsin enzyme at the concentration of $50 \mathrm{mg} / \mathrm{mL}$. The chymotrypsin inhibition activity did not seem to depend of the genotype type.

\subsection{Comparative Analysis of the Cowpea Genotypes on the Inhibition Potential of Trypsin and Chymotrypsin Enzymes}

The principal component analysis was performed on the basis of the different genotypes effect on trypsin and chymotrypsin inhibition. The figure 1 presents the repartition of the inhibition potentials of the different genotypes on trypsin and chymotrypsin enzymes in the biplot axis. 


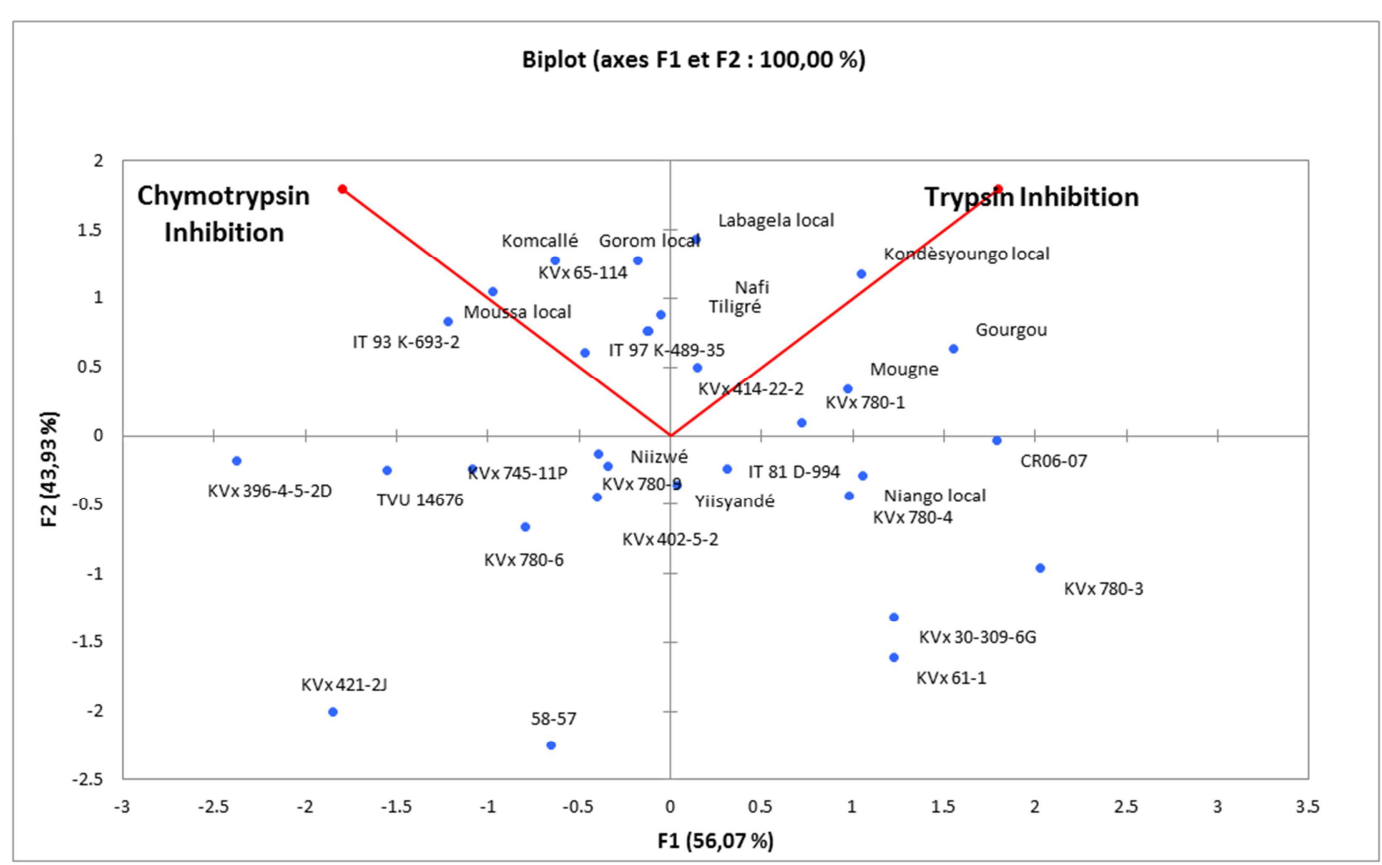

Figure 1. Principal component analysis of the different genotypes effect on trypsin and chymotrypsin inhibition activities.

The first two principal components explained $100 \%$ of the total variance. The first principal component (F1) accounting for $56.07 \%$ of the total variation separated the trypsin from chymotrypsin inhibition potentials of the different genotypes of cowpea. The second principal component (F2) accounting to $43.93 \%$ of the total variation separated the protease inhibition potential (trypsin and chymotrypsin) of the different genotypes of cowpea into two parts: more than $50 \%$ and less than $50 \%$ of the protease inhibition mean. The dendrogram constructed based on the different genotypes effect of trypsin and chymotrypsin inhibition activities divided the genotypes into three main classes, I, II and III (Figure 2). Class I is constituted by ten genotypes as follow: Komcallé, Labagela local, Gorom local, Nafi, KVx 65-114, IT 93K-693-2, Tiligré, IT 97 K-489-35, Moussa local and KVx 414-22-2. Class II has ten genotypes as follow: Kondesyoungo local, Gourgou, Mougne, CR06-07, KVx 780-1, Niango local, KVx 780-3, $\mathrm{KVx} 780-4, \mathrm{KVx} 30-309-6 \mathrm{G}$ and $\mathrm{KV} \times \mathrm{x} 61-1$. Class III is constituted by eleven genotypes of cowpea and comprised: KVx 396-4-5-2D, TVU 14676, Niizwé, KVx 745-11P, IT 81D994, Yiisyandé, KVx 780-9, KVx 780-6, KVx 402-5-2, KVx 421-2J and 58-57 genotypes.

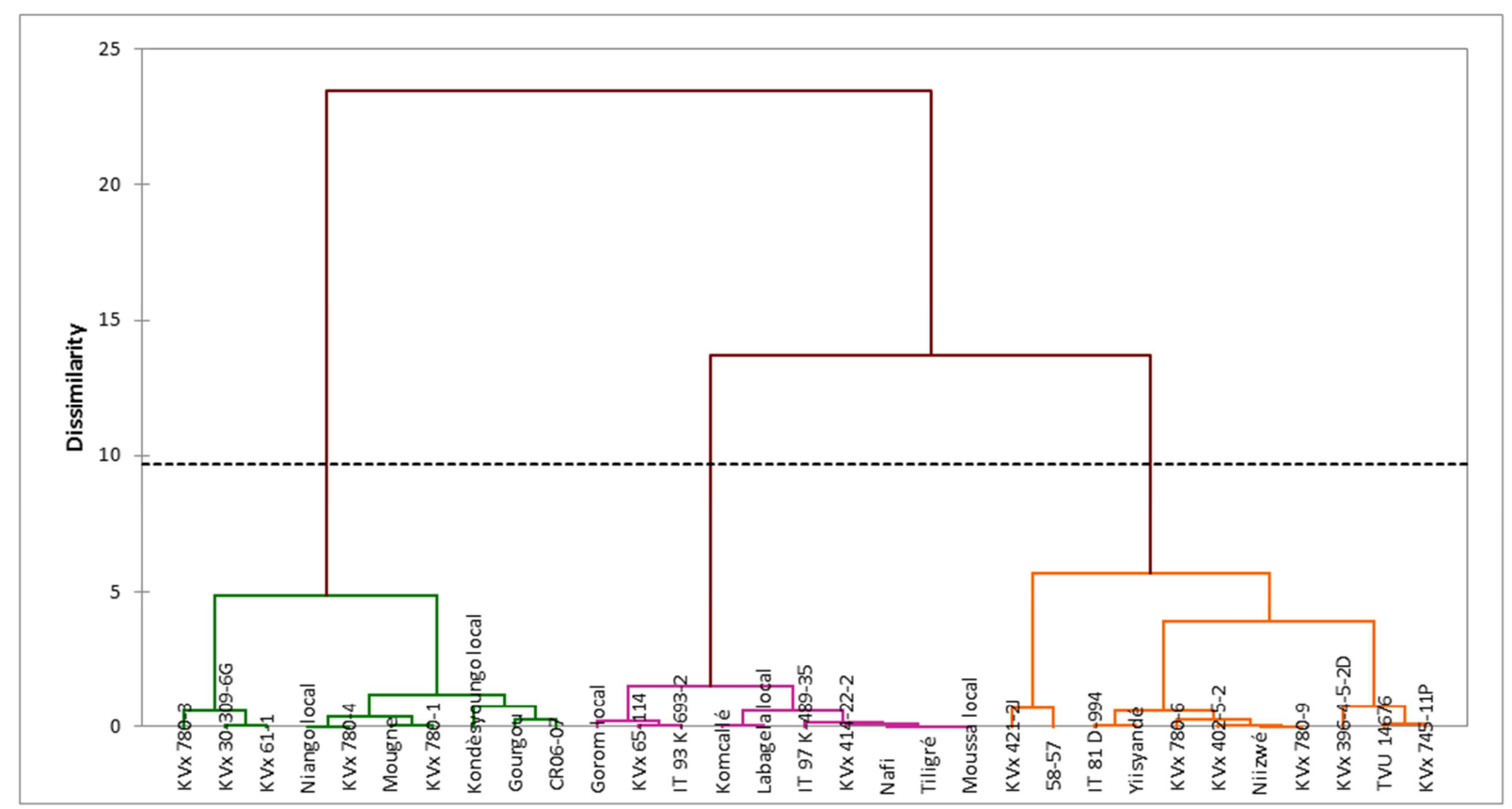

Figure 2. Dendrogram of the different genotypes effect on trypsin and chymotrypsin inhibition activities. 


\section{Discussion}

The consumption of legume like cowpea is highly recommended. This plant-enriched protein can be used in the human diet, especially in developing countries. Unfortunately, trypsin and chymotrypsin inhibitors can have many side effects on the protein digestion. The results of this study show that the quantity of trypsin and chymotrypsin inhibitors in cowpea seeds from Burkina Faso varies with genotypes, color or type of genotypes. The seeds of some cowpea genotypes studied are rich sources of trypsin and chymotrypsin inhibitors. Different studies have previously shown the positive or negative effect of protease inhibitors (trypsin and chymotrypsin inhibitors). Trypsin inhibitors in human foods inhibit protein digestion, cause growth depression, pancreatic hyperplasia and metabolic disturbance of sulfur and essential amino acid utilization [14, 18, 15]. Several studies showed that trypsin inhibitors (TI) could adversely affect the metabolism of methionine, threonine and valine by inhibiting proteolysis [19]. The role of chymotrypsin inhibitors is similar to trypsin inhibitors in that they limit protein digestibility. However, the site of activity is different in that chymotrypsin targets hydrophobic residues such as tyrosine, tryptophan and phenylalanine rather than lysine and arginine [20]. Many protease inhibitors (trypsin and chymotrypsin inhibitors) are already isolated from plants seeds. The Blackeyed pea Trypsin and Chymotrypsin Inhibitor (BTCI), a member of the BBI family was isolated from Vigna unguiculata (cultivar Seridó) seeds [21]. It was also reported that a Kunitz type trypsin inhibitor from Enterolobium contortisiliquum seeds strongly inhibited bovine trypsin, chymotrypsin and some serine proteases involved in the blood clotting cascade and the fibrinogen proteolysis [22]. Many trypsin chymotrypsin inhibitors are isolated in plants as antifungal proteins. Trypsin chymotrypsin inhibitor with potent antifungal protein was isolated from broad bean [22]. Several Kunitz inhibitors purified from legume seeds showed insecticidal activity [11] and serine PIs constitute an important component of the plant defense mechanism against pests and pathogens by inhibiting digestive proteases in the insect midgut $[23,24]$. It was observed that the cowpea genotype TVX-7, V-152 which are resistant against bruchids showed high levels of protease inhibitory activities [24] Their study showed strong correlation with protease inhibitory activities and the degree of field resistance to insects. Transgenic tobacco plant was produced with CPTI gene from cowpea [25].

In contrast, trypsin and chymotrypsin inhibitors could be linked to health-promoting properties. Protease inhibitors can act as anticarcinogenic agents $[14,20]$, act at many steps of the HIV lifecycle [26]. The TI of peas significantly inhibited human colon adenocarcinoma cells proliferation with an IC50 value of less than $50 \mu \mathrm{M}[14,26]$. The literature review also revealed the possible role of protease inhibitors as antimetastatic and antiinflammation [25]. The serine protease inhibitor (LC-PI-I) isolated from Lavatera cashmeriana seeds showed bactericidal potential against urinary tract infection, pneumonia and septicemia in humans [25]. The PIs from the leaves of Coccinia grandis also revealed the remarkable microbicidal potentiality against Klebsiella pneumoniae and Aspergillus flavus [25]. The presence of cystein amino acids in trypsin inhibitors explained their high nutritive value [27]. Kondèsyoungo local, Gourgou, CR06-07 and Labagela local genotypes that showed the high significant effects on trypsin inhibitory activity and $\mathrm{KVx} 396-4-5-2 \mathrm{D}$, IT $93 \mathrm{~K}-693-2$ (75.43\%), KVx 65-114 (75.036\%), Gorom local (73.84\%), Komcallé having the high chymotrypsin inhibitory potential could be used for human health purpose.

Most protease trypsin is thermolabile. The content of trypsin and chymotrypsin in cowpea seeds could be reduced during the cooking. It was showed that trypsin inhibitor activity in soybeans was reduced of $26.3 \%$ during heattreatments [18]. Trypsin inhibitors from Leguminosae seeds are reported to be great thermo resistance to high temperatures [28]. The reduction or elimination of enzyme inhibitors of pulses could be made using different food processes, like dehulling, soaking, boiling, roasting, autoclaving, micronization, microwave cooking, extrusion cooking, fermentation and germination [20]. It will be interesting to study the effect of these different food processes in trypsin and chymotrypsin inhibitors content of cowpea seeds. The PCA components analysis and the dendrogram constructed divided the thirty-one genotypes of cowpea used in this study into three class according to their protease inhibitory activities. The cowpea genotypes of class I possess the highest inhibitory activity of chymotrypsin as compared to trypsin inhibitory activity and at least 50\% inhibition of proteases. The class II genotypes showed the high inhibitory activity of trypsin as compared to chymotrypsin inhibitory activity. The genotypes belonging to class III possess the highest inhibitory activity of chymotrypsin as compared to trypsin inhibitory activity and less than $50 \%$ inhibition of proteases. This study suggests that it will be possible to breed the cowpea with low or high inhibition potential of protease enzymes.

\section{Conclusion}

The results obtained in this study contribute to the characterization of trypsin and chymotrypsin inhibitory activities of cowpea genotypes from Burkina Faso germplasm. The trypsin and chymotrypsin inhibitory activities in cowpea seed varies with genotype. Considerable differences in these enzyme inhibition activities were detected among all investigated seeds. This study constitutes an important contribution to a better understanding of the protease inhibitory potential of cowpea and further isolation of protease inhibitor could be used as an alternative strategy to control the insect's pests.

\section{Acknowledgements}

This research has been supported by TWAS under individual Fellowship Grant $\mathrm{N}^{\mathrm{O}}$ 14-218 RG/BIO/AF/AC_I UNESCO FR: 24028592 given to the first author. 


\section{References}

[1] A. Baptista, O. Pinho, E. Pinto, S. Casal, C. Mota, I. M. P. L. V. O. Ferreira, "Characterization of protein and fat composition of seeds from common beans (Phaseolus vulgaris L.), cowpea (Vigna unguiculata L. Walp) and bambara groundnuts (Vigna subterranea L. Verdc) from Mozambique", Food Measure 2016. doi 10.1007/s11694-016-9412-2.

[2] Y. Weng, A. Shi, W. S. Ravelombola, W. Yang, J. Qin, D. Motes, D. O. Moseley, P. Chen, "A Rapid method for measuring seed protein content in cowpea (Vigna unguiculata (L.) Walp)", American Journal of Plant Sciences, vol. 8, pp. 2387-2396, 2017. doi: 10.4236/ajps.2017.810161.

[3] G. Ddamulira, C. A. Santos, M. Alanyo, I. Ramathani, M. Maphosa, "Maturity, protein content and yield stability of cowpea in Uganda", South African Journal of Plant and Soil pp. 1-7, 2017.

http://dx.doi.org/10.1080/02571862.2016.1274919

[4] K. D. E. M. G Frota, L. A. R Lopes, I. C. V Silva, J. A. G Arês, "Molecular profile, purity and presence of trypsin inhibitors in cowpea protein isolates", Revista Caatinga, vol. 31 no. 1 , pp. 202-208, 2018. http://dx.doi.org/10.1590/1983$21252018 \mathrm{v} 31 \mathrm{n} 123 \mathrm{rc}$

[5] P. A. E. D Sombié, I. Ouedraogo, J. B. D. L. S Tignegré, A. Hilou, T. J. Ouedraogo, M. Kiendrébéogo, "Genotypic variation of mineral elements and phytate levels of thirty cowpeas (Vigna unguiculata L. walp.) varieties cultivated in Burkina Faso", J Food Chem Nutr 2018.

[6] P. A. E. D Sombié, M. Compaoré, A. Coulibaly, J. T. Ouédraogo, J. B. D. L. S Tignégré, M Kiendrébéogo, Antioxidant and phytochemical studies of 31 cowpeas (Vigna unguiculata (L. Walp.)) genotypes from Burkina Faso", Foods, vol. 7 no 9, 143, 2018. doi: 10.3390/foods7090143

[7] V. C. Silvestrini, D. B. Gonçalves, P. A. Granjeiro, J. A. D. Silva, "Anti-nutritional factors and digestibility of protein in Cayocar brasiliense seeds", Food Sci Technol., Vol 37, no 4, pp. 632-639, 2017. doi: http://dx.doi.org/10.1590/1678457X.28716.

[8] M. A. Ojo, B. I. O Ade-Omowaye, P. O. Ngoddy, “Processing effects of soaking and hydrothermal methods on the components and in vitro protein digestibility of Canavalia ensiformis", International Food Research Journal, Vol. 25, no 2, pp. 720-729, 2018.

[9] J. Ruan, Y. H. C Jun Yan, C. Jianping, W. Sun, G. Zhao, "Purification and properties of the chymotrypsin inhibitor from wild emmer wheat (Triticum dicoccoides) of Israel and its toxic effect on beet armyworm, Spodoptera exigua", Pesticide Biochemistry and Physiology 2017. doi: 10.1016/j. pestbp.2017.06.013.

[10] S. S. Mohanraj, S. D. Tetali, N. Mallikarjuna, A. DuttaGupta, K. Padmasree, "Biochemical properties of a bacterially-expressed Bowman-Birk inhibitor from Rhynchosia sublobata (Schumach.) Meikle seeds and its activity against gut proteases of Achaea janata", Phytochemistry, Vol 151, pp. 78-90, 2018. https://doi.org/10.1016/j.phytochem.2018.02.009.

[11] L. P. Dias, J. T. A. Oliveira, L. C. B Rocha-Bezerra, D. O. B Sousa, H. P. S Costa, N. M. S Araujo, A. F. U Carvalho, P. M.
S Tabosa, A. C. O Monteiro-Moreira, M. D. P Lobo, F. B. M. B Moreno, B. A. M Rocha, J. L. S Lopes, L. M Beltramini, I. M Vasconcelos, "A trypsin inhibitor purified from Cassia leiandra seeds has insecticidal activity against Aedes aegypti", Process Biochemistry, Vol 57, pp. 228-238, 2017. http://dx.doi.org/doi:10.1016/j.procbio.2017.03.015

[12] A. Nautiyal, N. Gaur, K. Singh, "Effect of soybean leaf protease inhibitor on the mean leaf area consumed by Spodopetra litura and Spilosoma obliqua larvae", Int J Curr Microbiol App Sci, Vol. 6, no 11, pp. 1435-1444, 2017, doi: https://doi.org/10.20546/ijcmas.2017.611.171

[13] M. Xiang, X. Zhang, Y. Deng, Y. Li, J. Yu, J. Zhu, X. Huang, J. Zhou, H. Liao, "Comparative transcriptome analysis provides insights of anti-insect molecular mechanism of Cassia obtusifolia trypsin inhibitor against Pieris rapae", Archives of Insect Biochemistry and Physiology, Vol. 97, no 1, e21427, 2018. https://doi.org/10.1002/arch.21427

[14] E. Guillamon, M. M. Pedrosa, C. Burbano, C. Cuadrado, M. D. C. Sanchez, M. Muzquiz, "The trypsin inhibitors present in seed of different grain legume species and cultivar", Food Chemistry, Vol. 107, pp. 68-74, 2008. doi: 10.1016/j.foodchem.2007.07.029

[15] N. Nikmaram, S. Y. Leong, M. Koubaa, Z. Zhu, F. J. Barba, R. Greiner, I. Oey, S. Roohinejad, "Effect of extrusion on the anti-nutritional factors of food products: An overview", Food Control 2017. doi: 10.1016/j.foodcont.2017.03.027.

[16] S. Banerjee, A. P. Giri, V. S. Gupta, S. K. Dutta, "Structurefunction relationship of a bio-pesticidal trypsin/chymotrypsin inhibitor from winged bean", International Journal of Biological Macromolecules 2016.

http://dx.doi.org/10.1016/j.ijbiomac.2016.12.018

[17] S. Klomklao, S. Benjakul, H. Kishimura, K. Osako, M. Tanaka, "A heat-stable trypsin inhibitor in adzuki bean (Vigna angularis), effect of extraction media, purification and biochemical characteristics", International Journal of Food Science \& Technology., Vol 45 no 1, pp. 163-169, 2009. doi: 10.1111/j.1365-2621.2009.02117.x.

[18] L. B Bueno-Borges, M. A Sartim, C. C Gil, S. V. Sampaio, P. H. V. Rodrigues, M. A. B. Regitano-d'Arce, "Sacha inchi seeds from sub-tropical cultivation: effects of roasting on antinutrients, antioxidant capacity and oxidative stability", Journal of Food Science and Technology, Vol 55, no 10, pp. 4159-4166, 2018. https://doi.org/10.1007/s13197-018-3345-1

[19] K. F Shireen, R. D. Pace, M. Egnin, C. S. Prakash, "Effects of dietary proteins and trypsin inhibitor on growth and lipid metabolism in hamsters", Mal J Nutr., Vol 7, no 1 \& 2, pp.: 114, 2001.

[20] L. Shi, K. Mu, S. D. Arntfield, M. T. Nickerson, "Changes in levels of enzyme inhibitors during soaking and cooking for pulses available in Canada", Journal of Food Science and Technology., Vol 54, no 4, 1014-1022, 2017. doi 10.1007/s13197-017-2519-6.

[21] G. A Joanitti, R. S. Sawant, V. P. Torchilin, S. M. D. Freitas, R. B. Azevedo, "Optimizing liposomes for delivery of Bowman-Birk protease inhibitors-Platforms for multiple biomedical applications", Colloids and Surfaces B: Biointerfaces 2018. https://doi.org/10.1016/j.colsurfb.2018.04.033. 
[22] B. Bijina, S. Chellappan, J. G. Krishna, S. M. Basheer, K. K. Elyas, A. H. Bahkali, M. Chandrasekaran, "Protease inhibitor from Moringa oleifera with potential for use as therapeutic drug and as seafood preservative", Saudi Journal of Biological Sciences., Vol. 18, no 3, pp. 273-281, 2011. doi: 10.1016/j.sjbs.2011.04.002.

[23] H. Kaur, A. Kaur, A. P. Kaur, P. J. Rup, S. K. Sohal, "Assessment of soybean inhibitor as a biopesticide against melon fruit fly, Bactrocera cucurbitae (Coquillett)", J Plant Dis Prot 2017. doi: 10.1007/s41348-017-0108-6.

[24] D. T. Prasad, N. S. Umpathv, R. Veeranna, "Genotypic variation in cowpea (Vigna unguiculata) cultivars in relation to insect resistance", $J$ Plant Biochemistry \& Biotechnology., Vol 5, pp. 47- 49, 1996.

[25] V. G. M. Krishnan, K. Murugan,"Purification, characterization and kinetics of protease inhibitor from fruits of Solanum aculeatissimum Jacq", Food Science and Human Wellness 2015, Vol 4, no (3), pp. 97-107. http://dx.doi.org/10.1016/j.fshw.2015.06.003.
[26] Z. Lv, Y. Chu, Y. Wang, "HIV protease inhibitors: a review of molecular selectivity and toxicity", HIV AIDS (Auckl), Vol. 7, pp. 95-104, 2015. http://dx.doi.org/10.2147/HIV.S79956.

[27] S. P. Stanojević, M. B. Barać, M. B. Pešić, B. V. VucelićRadović, "The influence of soybean genotypes and HTC processing method on trypsin inhibitor activity of soymilk". Journal of Agricultural Sciences, Vol 61, no 3, pp. 271-279, 2016. doi: 10.2298/JAS1603271S.

[28] D. D. D. Souza, R. M. P. Brandão-Costa, W. W. C. Albuquerque, A. L. F. Porto, "Partial purification and characterization of a trypsin inhibitor isolated from Adenanthera pavonina L. seeds", South African Journal of Botany., Vol. 104, pp. 30-34, 2016. http://dx.doi.org/10.1016/j.sajb.2015.11.008. 